\title{
Landfill Leachate Nutrient Removal Using Intermittent Aeration
}

\author{
Paraschos Melidis
}

Received: 11 February 2014 / Accepted: 30 April 2014 / Published online: 27 May 2014

(C) Springer International Publishing Switzerland 2014

\begin{abstract}
The aim of this study was to investigate the biological removal of nitrogen and phosphorus from an intermediate age leachate diluted with domestic wastewater. A sequencing batch reactor (SBR) with alternate aeration was operated under aerobic (Ox) and anoxic (Ax) phases of different durations ( $\mathrm{Ox} 3$ or $6 \mathrm{~h}$ and $\mathrm{Ax} \mathrm{1,2}$ or $3 \mathrm{~h}$ ), for a total cycle period of 24 or $48 \mathrm{~h}$. Crude glycerol from biodiesel production was used as external carbon source to improve denitrification. Leachate mixture of $15 \% \mathrm{v} / \mathrm{v}$ in municipal wastewater was found to be the optimum concentration at which no adverse effects were observed. Experiments without the use of external carbon source resulted in a low denitrification potential and a strong $\mathrm{NO}_{3}{ }^{-}{ }^{-} \mathrm{N}$ and $\mathrm{NO}_{2}{ }^{-}-\mathrm{N}$ accumulation. By contrast, denitrification was effectively achieved by using crude glycerol at the beginning of the anoxic phase, where a $\mathrm{sCOD} / \mathrm{NO}_{\mathrm{x}}-\mathrm{N}$ ratio of 5 was created. Comparing the different operation strategies applied, $6 \mathrm{~h}$ aeration and $2 \mathrm{~h}$ anoxic phase at the $48 \mathrm{~h}$-cycle period scheme resulted in the greatest TKN, $\mathrm{NH}_{4}{ }^{+}-\mathrm{N}, \mathrm{NO}_{3}{ }^{-} \mathrm{N}$ and $\mathrm{NO}_{2}{ }^{-}-\mathrm{N}$ removal efficiencies, estimated as 75.9, 75.7, 99.9 and $99.9 \%$, respectively. For efficient phosphorus removal, sufficient time for the reduction of nitrate concentration (below $5 \mathrm{mg} / \mathrm{L}$ $\mathrm{NO}_{3}{ }^{-}-\mathrm{N}$ ) and the highest $\mathrm{PO}_{4}{ }^{3-}-\mathrm{P}$ release at the non-aeration stage was needed in order to favor a poly-P enriched biomass. In conclusion, an intermittently aerated SBR working at various aerobic/anoxic duration phases was used to treat a mixture of wastewater and semi-mature landfill leachate. Glycerol added as external carbon source was necessary to complete denitrification. Enhanced phosphorus removal was achieved at sufficient anoxic phase duration $(2-3 \mathrm{~h})$.
\end{abstract}

Keywords Landfill leachate - Biological treatment - Intermittent aeration · Nutrient removal · Crude glycerol

\section{Introduction}

An environmental issue of significant importance is the treatment of landfill leachate, as stricter environmental requirements are set both for ground and surface waters (Renou et al.

P. Melidis $(\triangle)$

Department of Environmental Engineering, School of Engineering, Democritus University of Thrace, Vas. Sofias 12, 67100 Xanthi, Greece

e-mail: pmelidis@env.duth.gr 
2008; Raghab et al. 2013). The biological treatment, due to reliability, simplicity and reasonable cost, is one of the most common ways for the pre-treatment of landfill leachate (Kurniawan et al. 2010).

The effectiveness of such a process is based on the high degradation rates regarding the organic and nitrogen content of immature leachates, for BOD/COD value greater than 0.4. However, most common problems in biological treatment of semi-mature and mature landfill leachates are mainly the high COD and ammonium content, the presence of heavy metals and the low BOD/COD ratio (Park et al. 2001). Therefore, the combination of both chemical and biological methods in most cases results in the satisfactory and efficient treatment of such hazardous effluents (Abbas et al. 2009). Aerobic, anaerobic and anoxic processes are among the biological treatment methods used ( $\mathrm{Im}$ et al. 2001) in order to remove carbonaceous compounds as well as nutrients like nitrogen and phosphorus, minimizing at the same time the cost of secondary treatment.

The sequencing batch reactor (SBR) is one of the most popular systems used for biological treatment of landfill leachate (Neczaj et al. 2005). In order to avoid undesirable effects on the activated sludge process, mixing of domestic wastewater and leachate can reduce the leachate strength and sustain the effectiveness of the method (Diamadopoulos et al. 1997; Çeçen and Aktaş 2004). High concentration of free ammonia, heavy metals and other organic microcontaminants in high-strength leachates cause the inhibition of nitrification. Nitrite oxidizing bacteria (NOB) exhibit greater sensitivity in the presence of certain inhibitors compared to ammonia oxidizing bacteria $(\mathrm{AOB})$ and nitrite accumulation is observed when the nitrite oxidation process is prevented (Rhee et al. 1997).

Satisfactory denitrification requires a $\mathrm{rbCOD} / \mathrm{N}$ ratio within 4 and 15 . In the case of unfavourable influent $\mathrm{COD} / \mathrm{N}$ ratio, an external electron donor is required. Methanol, ethanol, acetate and hydrolysate from the fermentation of primary sludge are the most common external organic sources used for dissimilatory nitrate reduction (Bolzonella et al. 2001). They are added in the anoxic phase of various Biological Nitrogen Removal (BNR) systems, enhancing electron donor availability (Isaacs and Henze 1995). Kulikowska and Bernat (2013) have previously studied the capability of landfill leachate to be denitrified through a prior ammonium oxidation to nitrite under low dissolved oxygen concentration using glycerine as the external carbon source, achieving high nitrogen removal efficiencies and low biomass productivity.

By contrast, only a few works dealing with the biological landfill leachate treatment investigated the exact periodical interchange of ammonia oxidation to nitrate and the following denitrification process under successive anoxic and aerobic phases. Thus, the aim of this study was to investigate the biological removal of nitrogen and phosphorus from an intermediate age leachate diluted with domestic wastewater. Crude glycerol from biodiesel production was used as external carbon source to improve the $\mathrm{COD} / \mathrm{N}$ ratio necessary for denitrification. Moreover, the competition of nitrifiers and phosphorus removing organisms (PAOs) for substrate, and the determination of the crucial nitrate concentration which allows PAOs to release $\mathrm{PO}_{4}-\mathrm{P}$ during the anoxic phase are among the main experimental aspects of the current study.

\section{Materials and Methods}

\subsection{Leachate Characteristics}

The leachate, which was originated from Xanthi's municipal landfill (North Greece), was stored at $4{ }^{\circ} \mathrm{C}$ until it was used. The characteristics of the leachate used in the present study 
corresponded to a middle age landfill, as indicated by the BOD/COD value of 0.24 (Table 1). The physicochemical composition of domestic sewage used in the experiment was: $\mathrm{pH}=7.6 \pm$ $0.2, \mathrm{EC}=1,217 \pm 139 \mu \mathrm{S} / \mathrm{cm}, \mathrm{COD}=400 \pm 43.7 \mathrm{mg} / \mathrm{L}, \mathrm{BOD}=214 \pm 35.1 \mathrm{mg} / \mathrm{L}, \mathrm{TKN}=65 \pm$ $8.7 \mathrm{mg} / \mathrm{L}, \mathrm{NH}_{4}-\mathrm{N}=45 \pm 4.2 \mathrm{mg} / \mathrm{L}$ and $\mathrm{TP}=6.5 \pm 1.2 \mathrm{mg} / \mathrm{L}$.

\subsection{Experimental Set-Up}

The experiments were conducted in a 5-L bench-scale reactor under a working volume of $4 \mathrm{~L}$. The SBR operated in a scheme of four phases, consisting of the effluent filling, the anoxic and aerobic treatment and the sludge settling, where a solids retention time (SRT) of approximately 12 days was established. The temperature was kept constant at $20^{\circ} \mathrm{C}$. The $\mathrm{pH}$, the temperature (T) and the dissolved oxygen (DO) of the activated sludge mixed liquor were continuously monitored by the respective probes. Before start-up, the reactor was filled with $3 \mathrm{~L}$ of $10 \% \mathrm{v} / \mathrm{v}$ leachate/domestic wastewater mixture and operated in batch mode under continuous aeration and mixing for several days in order to acclimatize the microbial biomass to the leachate addition. The inoculum was activated sludge from an extended aeration wastewater treatment plant, with the following characteristics: MLSS $3.1 \mathrm{~g} / \mathrm{L}$; MLVSS $2.51 \mathrm{~g} / \mathrm{L} ; \mathrm{pH} 7.78$; EC $952 \mu \mathrm{S} / \mathrm{cm}$. The reactor was operated under alternate aerobic (Ox) and anoxic (Ax) phases after the start-up period. Dissolved oxygen was set above $2 \mathrm{mg} / \mathrm{L}$ during the aeration phase and dropped quickly below $0.1 \mathrm{mg} / \mathrm{L}$ in the anoxic phase. The time period of aerobic/anoxic phases and the total cycle duration (until the next effluent filling) examined were $3 \mathrm{~h} / 1 \mathrm{~h}-24 \mathrm{~h}$, $3 \mathrm{~h} / 3 \mathrm{~h}-24 \mathrm{~h}, 3 \mathrm{~h} / 3 \mathrm{~h}-48 \mathrm{~h}$ and 6 h/2 h-48 h, respectively. Crude glycerol (1,000 g/L COD, $\mathrm{pH} 10.7)$ was derived from a biodiesel production plant located in Northern Greece, containing $15.7 \%$ water, $7.1 \%$ methanol, $26.5 \%$ soaps, $50.6 \%$ glycerin and $0.1 \%$ catalyst. Crude glycerol was applied as an aqueous solution in order to achieve a BOD-to-COD ratio of 0.5.

\subsection{Analytical Techniques}

All analyses were carried out in accordance to the Standard Methods (APHA 1998). COD measurement was performed by the dichromate closed reflux method. $\mathrm{NH}_{4}{ }^{+}-\mathrm{N}$ was determined by steam distillation and subsequent titration. TKN analysis was performed by the same procedure followed for ammonia, although after sample digestion. Total alkalinity was estimated by titrating of the sample against a $0.1 \mathrm{~N} \mathrm{HCl}$ solution until the equivalence point

Table 1 Leachate characteristics

\begin{tabular}{llllll}
\hline Characteristic & Unit & Min & Max & Mean & st dev \\
\hline $\mathrm{pH}$ & & 7.45 & 7.95 & 7.8 & 0.198 \\
$\mathrm{EC}$ & $\mathrm{mS} / \mathrm{cm}$ & 31.9 & 33.1 & 32.3 & 0.493 \\
$\mathrm{tCOD}$ & $\mathrm{mg} / \mathrm{L}$ & 5,478 & 5,595 & 5,565 & 49.4 \\
$\mathrm{sCOD}$ & $\mathrm{mg} / \mathrm{L}$ & 5,222 & 5,334 & 5,306 & 47.1 \\
$\mathrm{BOD}$ & $\mathrm{mg} / \mathrm{L}$ & 1,230 & 1,289 & 1,263 & 23.5 \\
$\mathrm{BOD} / \mathrm{COD}$ & & 0.23 & 0.24 & 0.24 & 0.006 \\
$\mathrm{TKN}$ & $\mathrm{mg} / \mathrm{L}$ & 1,989 & 2,121 & 2,042 & 50.7 \\
$\mathrm{NH}_{3}-\mathrm{N}$ & $\mathrm{mg} / \mathrm{L}$ & 1,857 & 1,980 & 1,906 & 47.3 \\
$\mathrm{PO}_{4}{ }^{3-}-\mathrm{P}$ & $\mathrm{mg} / \mathrm{L}$ & 1.7 & 3.8 & 2.7 & 0.23 \\
$\mathrm{Alkalinity}$ & $\mathrm{mg} \mathrm{CaCO} / \mathrm{L}$ & 4,765 & 6,513 & 5,891 & 677 \\
\hline
\end{tabular}


(pH 4.3-4.5). The $\mathrm{NO}_{2}{ }^{-}-\mathrm{N}, \mathrm{NO}_{3}{ }^{-}-\mathrm{N}$ and $\mathrm{PO}_{4}{ }^{3-}-\mathrm{P}$ concentrations were determined by ion chromatography (Dionex ICS 3000). For pH and alkalinity measurements, a WTW pH-meter 340i supported with a SenTix ${ }^{\circledR} \mathrm{pH}$ electrode was used.

\section{Results and Discussion}

\subsection{Determination of the Optimum Raw Leachate/Domestic Wastewater Ratio}

Leachate of low BOD/COD ratio is difficult to be treated biologically (Xie et al. 2012). Dilution with process water or combined treatment with municipal wastewater is necessary to overcome the inhibitory effects of salinity, and the toxicity of heavy metals and recalcitrant substances (Diamadopoulos et al. 1997; Çeçen and Aktaş 2004). Investigations were first conducted to find the optimum dilution rate using different amounts of leachate and treated wastewater effluent. Figure 1 presents the monitored parameters, i.e., $\mathrm{TKN}, \mathrm{NH}_{3}-\mathrm{N}$ and sCOD. The biological removal efficiencies of all three parameters were decreased by increasing leachate participation rate. TKN removal efficiency was decreased by $86.5 \pm 0.6 \%, 83.5 \pm$ $0.7 \%, 27.3 \pm 1.0 \%, 22.7 \pm 1.0 \%, 14.4 \pm 1.4 \%$ (mean \pm st.dev.) for $10 \%, 15 \%, 20 \%, 25 \%$, $30 \%$ leachate mixtrure application, respectively, with the exception of $35 \%$ mixture which gave a value of $26.6 \pm 2.0 \%$. The $\mathrm{NH}_{3}-\mathrm{N}$ values, which represent approximately $89 \%$ of the TKN values, followed the same removal pattern like TKN. sCOD was decreased by $72.2 \pm 2.0$, $90.0 \pm 1.8,17.9 \pm 1.1,16.9 \pm 1.2,17.8 \pm 1.1$ and $23.8 \pm 1.2 \%$ (mean \pm st.dev.) at $15,20,25,30$ and $35 \%$ leachate mixture application, respectively. The highest sCOD and nitrogen removals were obtained at the end of the $24 \mathrm{~h}$ experiment for leachate concentrations up to $15 \%$. Inhibition of the biological activity is known to occur at higher mixing ratios of leachate (Gotvajn et al. 2012; Kim et al. 2006). Therefore, application of $15 \%$ leachate was chosen for further experiments.

\subsection{Nitrogen Removal Efficacy in the Absence of External Carbon Source}

Experiments (at $3 \mathrm{~h} / 1 \mathrm{~h}$ aerobic/anoxic phases and 24,48 or $72 \mathrm{~h}$ cycle durations) without the use of external carbon source resulted in a reduction of TKN and ammonia nitrogen (Fig. 2). The soluble COD was also reduced, especially for the $48 \mathrm{~h}$-cycle period application. Strong $\mathrm{NO}_{3}{ }^{-}$and $\mathrm{NO}_{2}{ }^{-}$accumulation was observed after the depletion of $\operatorname{sCOD}(24 \mathrm{~h})$.

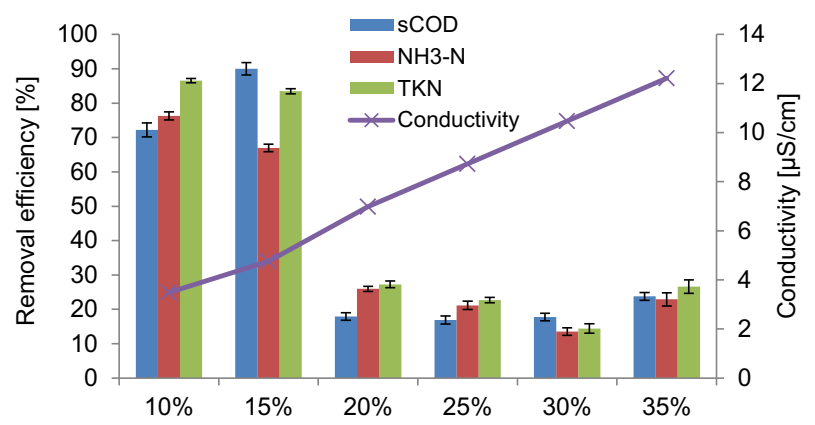

Fig. 1 sCOD, $\mathrm{NH}_{3}-\mathrm{N}$ and $\mathrm{TKN}$ removal efficiencies and sample conductivity (line) at different leachate concentrations 


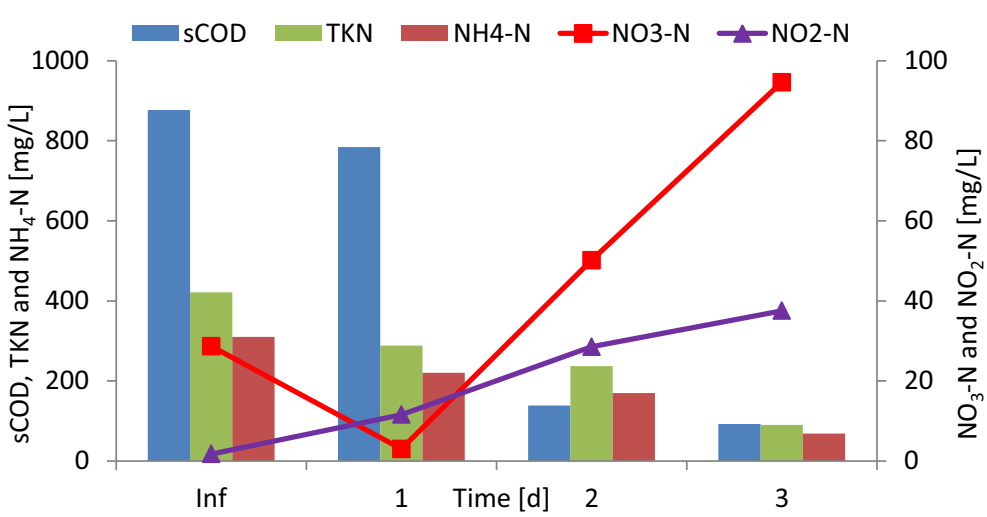

Fig. 2 Changes in SCOD and nitrogenous compound concentrations in the absence of external carbon source

This trend was expected due to the low $\mathrm{BOD} / \mathrm{sCOD}$ ratio $(0.24)$ and a shortage in readily biodegradable COD, which is very important for the denitrification. Nitrite accumulation was significantly higher than nitrate at day 1 and the $\mathrm{NO}_{2}{ }^{-}-\mathrm{N} / \mathrm{NO}_{\mathrm{x}}-\mathrm{N}$ ratio increased gradually from 0.2 to 0.7 during the start-up period at day 1 . The inhibition of ammonium and nitrite oxidation by free ammonia and nitrous acid is well known (Zhou et al. 2011; Vadivelu et al. 2007). The inhibitory effects of substrate concentration, among other factors, such as $\mathrm{pH}, \mathrm{T}$, DO and SRT, are strong and complex, due to unionization phenomena. It was observed that both ammonium and nitrite oxidations are inhibited by unionized free ammonia. Moreover, Bae et al. (2001) reported that nitrite accumulation occurred at initial free ammonia concentration of $4.7 \mathrm{mg} / \mathrm{L}$, giving a high $\mathrm{NO}_{2}{ }^{-} / \mathrm{NO}_{\mathrm{X}}$ ratio (up to $77 \%$ ) in a batch reactor. On the other hand, the works of Vadivelu et al. (2007) indicated that nitrite oxidation could be selectively inhibited by free nitrous acid. Nitrite oxidation could be affected more than ammonium oxidation by free ammonia, resulting in accelerating nitrite accumulation in a strong nitrogenous environment. Effluent alkalinity was in any case over $460 \mathrm{mg} / \mathrm{L}\left(\mathrm{as} \mathrm{CaCO}_{3}\right)$, indicating a stable nitrification process.

\subsection{Nitrogen Removal Efficacy in the Presence of External Carbon Source}

Nitrogen removal was improved by adding external carbon source at the beginning of the anoxic phase. Crude glycerol, from biodiesel production, was chosen to a $\mathrm{sCOD} / \mathrm{NO}_{\mathrm{x}}-\mathrm{N}$ ratio of 5 (Kulikowska and Bernat 2013; Sun et al. 2012). The performance of the intermittently aerated and fed bioreactor was examined under different aeration/anoxic phase duration and cycle period lengths using $15 \% \mathrm{v} / \mathrm{v}$ leachate in the presence of crude glycerol (Table 2).

Table 2 Experimental set-up: Aerobic and anoxic phase duration and total cycle period

\begin{tabular}{llll}
\hline & Aerobic & Anoxic & Total cycle period \\
\hline Experiment I & $3 \mathrm{~h}$ & $1 \mathrm{~h}$ & $24 \mathrm{~h}$ \\
Experiment II & $3 \mathrm{~h}$ & $3 \mathrm{~h}$ & $24 \mathrm{~h}$ \\
Experiment III & $3 \mathrm{~h}$ & $3 \mathrm{~h}$ & $48 \mathrm{~h}$ \\
Experiment IV & $6 \mathrm{~h}$ & $2 \mathrm{~h}$ & $48 \mathrm{~h}$ \\
\hline
\end{tabular}


Nitrification was examined at 3 and $6 \mathrm{~h}$ aeration phase intervals (Fig. 3 and Table 2). In experimental set-ups I and II, TKN and $\mathrm{NH}_{3}-\mathrm{N}$ removal efficiencies varied within 44.7-46.8 and $33.1-33.7 \%$, with a mean value of 45.8 and $33.4 \%$ respectively. By using a cycle period of $48 \mathrm{~h}$ (experimental set-up III), the mean TKN and $\mathrm{NH}_{3}-\mathrm{N}$ removal efficiencies increased, as expected, by 58 and $39.4 \%$, respectively. The highest nitrogen oxidation values were achieved during an aeration phase of $6 \mathrm{~h}$, which resulted in $\mathrm{TKN}$ and $\mathrm{NH}_{3}-\mathrm{N}$ removal of 77.2 and $77.5 \%$, respectively. However, the residual concentrations of $\mathrm{TKN}$ and $\mathrm{NH}_{3}-\mathrm{N}$ should be subjected to further post-treatment in order to meet the legislation criteria for disposal. Denitrification was examined at three different anoxic phase periods, i.e., 1, 2 and $3 \mathrm{~h}$ (Table 2). The lowest denitrification efficiency was achieved at $1 \mathrm{~h}$ anoxic phase, resulting in $\mathrm{NO}_{3}{ }^{-} \mathrm{N}$ and $\mathrm{NO}_{2}{ }^{-} \mathrm{N}$ decrease of $27.1 \pm 0.76$ and $78.1 \pm 0.9 \%$, respectively. This indicates an insufficient denitrification period. By increasing the anoxic time period from 1 to $3 \mathrm{~h}$, the $\mathrm{NO}_{3}{ }^{-}-\mathrm{N}$ removal efficiency was found to be $83.2 \pm 0.9 \%$. By further increasing the cycle time period to $48 \mathrm{~h}$, almost complete $\mathrm{NO}_{3}{ }^{-}-\mathrm{N}$ and $\mathrm{NO}_{2}{ }^{-}-\mathrm{N}$ removal was achieved (removal efficiency of 99.4 $\pm 0.46 \%$ ). Complete denitrification was also achieved using $2 \mathrm{~h}$ denitrification phase at $48 \mathrm{~h}$ total cycle period length. The residual alkalinity was higher than that estimated in the absence of external carbon source addition. In any case, alkalinity was over $1,000 \mathrm{mg} / \mathrm{L}\left(\right.$ as $\left.\mathrm{CaCO}_{3}\right)$ due to the contribution of denitrification process.

Figure 4 presents the concentration profiles of TKN, ammonia, nitrate and nitrite nitrogen at the operation mode of $6 \mathrm{~h}$ aerobic and $2 \mathrm{~h}$ anoxic phase. Readily biodegradable glycerol was added at the beginning of every anoxic phase in order to initiate denitrification. Continuous decrease in TKN (from 249 to $58.8 \mathrm{mg} / \mathrm{L}-76.4 \%$ removal) and ammonia (from 193 to $28 \mathrm{mg}$ ) $\mathrm{L}-85 \%$ removal) were observed, while nitrate $(\max 19.1 \mathrm{mg} / \mathrm{L})$ and nitrite $(\max 24.1 \mathrm{mg} / \mathrm{L})$ were produced in the aerobic phase and then completely denitrified in the anoxic phase $(0 \mathrm{mg} /$ L).

During the aeration phase, ammonia oxidizing bacteria (AOB) produced nitrite, and successively, the nitrite oxidizing bacteria (NOB) formed nitrate. Both nitrogen species were completely reduced in the following denitrification phase. Interestingly, higher $\mathrm{NO}_{2}{ }^{-} \mathrm{N}$ concentration compared to that of $\mathrm{NO}_{3}{ }^{-} \mathrm{N}$ was observed during the first three cycles of the batch experiment, probably due to the toxic effects of the free ammonia to nitrite oxidizers. After the decrease of ammonia nitrogen concentration by $72 \%$ within a period of $22 \mathrm{~h}$, NOB activity was restored and nitrate nitrogen concentration was higher in the following cycles compared to nitrite nitrogen concentrations. In any case, both nitrogen species were completely reduced at the end of the following denitrification phase.

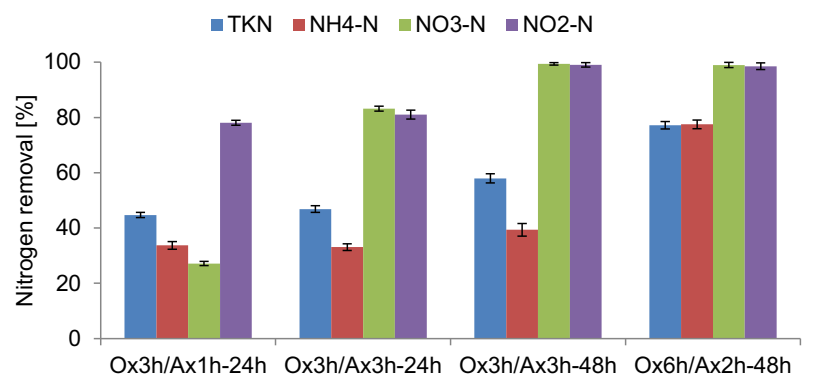

Fig. 3 Nitrogen species removal efficiencies at different anoxic and aerobic phase durations and total cycle periods in the presence of external carbon source 


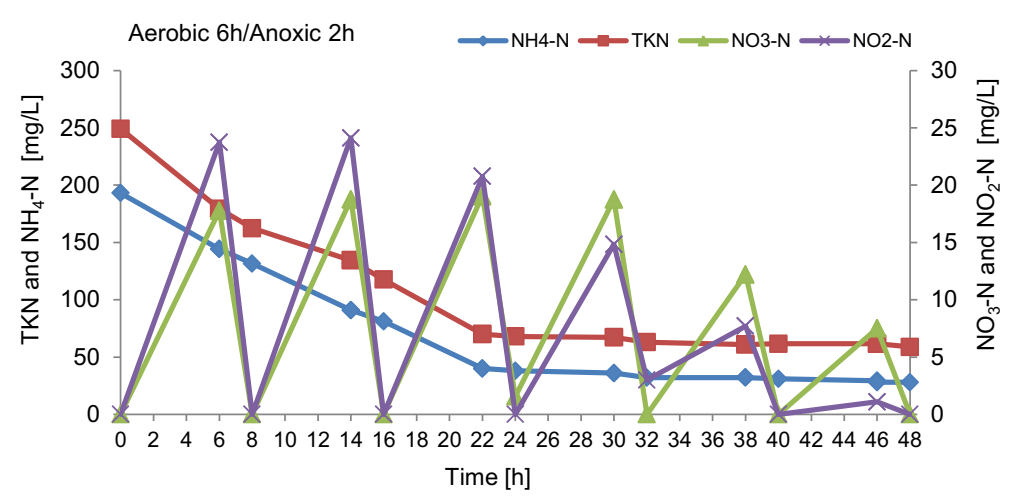

Fig. 4 Concentration profiles with the addition of external carbon source at the operation mode aerobic $6 \mathrm{~h} /$ anoxic $2 \mathrm{~h}$

\subsection{Phosphorus Removal}

In sequencing batch reactors, phosphorus removal is accomplished by the establishment of anaerobic time sequence or through the increase of the anoxic phase duration (Wang et al. 2008; Gao et al. 2013). In this study, different anoxic phase periods were examined in order to increase phosphorus removal. Figure 5 presents the phosphorus concentration profile at successive anoxic/aerobic phases during the experimental set-ups I (Aerobic $3 \mathrm{~h} /$ Anoxic $1 \mathrm{~h}$ $24 \mathrm{~h}$ ), III (Aerobic $3 \mathrm{~h} /$ Anoxic3h-48 h) and IV (Aerobic $6 \mathrm{~h} /$ Anoxic $2 \mathrm{~h}-48 \mathrm{~h}$ ). It is obvious that $1 \mathrm{~h}$ anoxic phase was not enough for phosphate release since $\mathrm{PO}_{4}{ }^{3-}$-P concentration remained almost constant after $24 \mathrm{~h}$. Experiments III and IV resulted in phosphorus release during the anoxic phase, while phosphorus uptake was observed in the successive aerobic phase, indicating the system ability of performing enhanced biological phosphorus removal (EBPR) (Guo et al. 2011; Akin and Ugurlu 2004). In both experimental conditions, negligible $\mathrm{PO}_{4}{ }^{3-}$-P concentrations remained in the effluent at the end of the aerobic phase.

The influence of $\mathrm{NO}_{3}-\mathrm{N}$ concentration on the phosphorus release during the anoxic phase was also examined (Akin and Ugurlu 2004; Kuba et al. 1994). Figure 6 presents the detailed profiles of $\mathrm{PO}_{4}{ }^{3-}-\mathrm{P}$ and $\mathrm{NO}_{3}{ }^{-}-\mathrm{N}$ concentrations and $\mathrm{pH}$ during the experimental set-ups I, III and IV. In the experimental set-up I, the implementation of the lowest anoxic phase duration $(1 \mathrm{~h})$ resulted in the worst performance (Fig. 6a). This anoxic phase period was insufficient for both $\mathrm{NO}_{3}{ }^{-}-\mathrm{N}$ removal and PAOs enrichment (which can enhance the $\mathrm{PO}_{4}{ }^{3-}$-P release in the

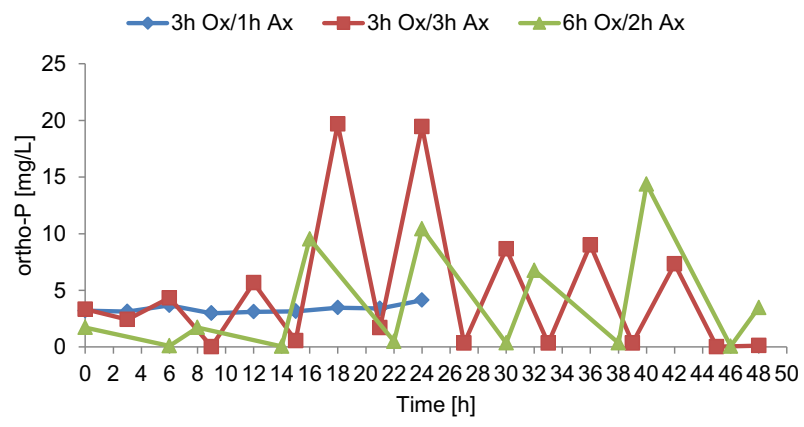

Fig. 5 ortho-P concentration profiles along various anoxic/aerobic operation periods 
non-aerated phase). However, in the other experimental set-ups, where longer anoxic phases were applied ( 2 and 3 h) (Fig. $6 \mathrm{~b}$ and c), effective EBPR was achieved. During $3 \mathrm{~h} / 3 \mathrm{~h}$ aerobic/ anoxic phases, $\mathrm{NO}_{3}{ }^{-}-\mathrm{N}$ was decreased from 25 to $5 \mathrm{mg} / \mathrm{L}$ (after $60 \mathrm{~min}$ in the anoxic phase) and the $\mathrm{PO}_{4}{ }^{3-}-\mathrm{P}$ concentration was increased in the non-aerated phase from 5 to $35 \mathrm{mg} / \mathrm{L}$. In
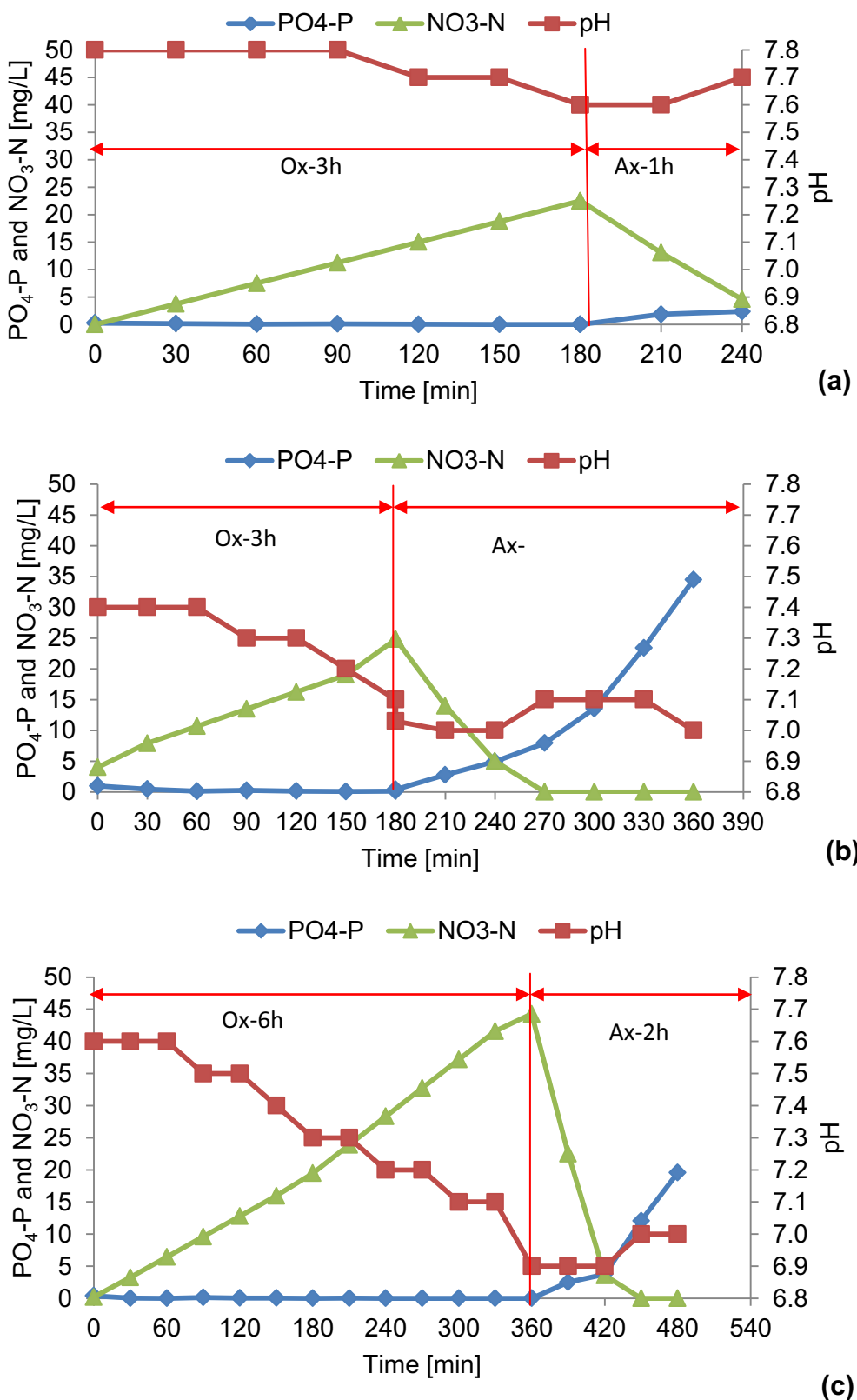

Fig. 6 ortho- $\mathrm{P}, \mathrm{NO}_{3}{ }^{-}-\mathrm{N}$ and $\mathrm{pH}$ profiles along various anoxic/aerobic operation periods: a) $3 \mathrm{~h}$ aerobic/1 $\mathrm{h}$ anoxic; b) $3 \mathrm{~h}$ aerobic/3 $\mathrm{h}$ anoxic; and c) $6 \mathrm{~h}$ aerobic/2 $\mathrm{h}$ anoxic 
the case of $6 \mathrm{~h}$ aerobic and $2 \mathrm{~h}$ anoxic phase, $\mathrm{NO}_{3}{ }^{-}-\mathrm{N}$ was decreased from 44.3 to $5 \mathrm{mg} / \mathrm{L}$ and the $\mathrm{PO}_{4}{ }^{3-}$-P concentration increased in the non-aerated phase from 5 to $20 \mathrm{mg} / \mathrm{L}$.

The nitrification process produces hydrogen ions and decreases $\mathrm{pH}$ (Peng et al. 2003). The latter depends on the duration length of the aerobic phase, as shown in Fig. 6. The lowest $\mathrm{pH}$ variation (from $\mathrm{pH} 7.6$ to 7.8 ) was observed during the experimental set-up I, while the $\mathrm{pH}$ varied more widely at the following experimental set-ups (from $\mathrm{pH} 7.0$ to 7.6) where longer anoxic phases were applied.

\section{Conclusions}

The aim of the present study was to investigate the nitrogen and phosphorus removal efficiencies of an intermittently aerated SBR working at various aerobic/anoxic phases duration, where semi-mature landfill leachate was treated. Experimental results showed that the optimum mixing ratio of raw leachate to domestic wastewater was 0.15 (15\% leachate concentration), which appears to be a practical upper limit for biological nutrient removal in semi-mature leachates. In the absence of external carbon source, moderate denitrification efficiency was achieved and strong $\mathrm{NO}_{3}{ }^{-}-\mathrm{N}$ and $\mathrm{NO}_{2}{ }^{-}-\mathrm{N}$ accumulation was observed. Aeration phase of 6 and $48 \mathrm{~h}$ cycle period (until the next effluent filling) resulted in 77.2 and $77.5 \%$ TKN and $\mathrm{NH}_{4}{ }^{+}-\mathrm{N}$ removal, respectively. Crude glycerol from biodiesel production increased the denitrification efficacy, achieving 83 and $99.4 \%$ as well as 81 and $99 \% \mathrm{NO}_{3}{ }^{-} \mathrm{N}$ and $\mathrm{NO}_{2}{ }^{-} \mathrm{N}$ removal efficiencies under 2 and $3 \mathrm{~h}$ anoxic phase duration, respectively. Phosphorus release at the non-aerated phase was observed when nitrate- $\mathrm{N}$ was reduced below $5 \mathrm{mg} / \mathrm{L}$ and the anoxic phase duration was longer than $2 \mathrm{~h}$, resulting in complete $\mathrm{PO}_{4}{ }^{3-}-\mathrm{P}$ uptake at the end of the successive aerobic phase.

\section{References}

Abbas AA, Jingsong G, Ping LZ, Ya PY, Al-Rekabi WS (2009) Review on landfill leachate treatments. Am J Appl Sci 6(4):672-684

Akin BS, Ugurlu A (2004) The effect of an anoxic zone on biological phosphorus removal by a sequential batch reactor. Bioresour Technol 94(1):1-7

APHA, AWWA (American Public Health Association, American Water Works Association) (1998) Standard methods for the examination of water and wastewater, 20th edn. Washington DC

Bae W, Baek S, Chung J, Lee Y (2001) Optimal operational factors for nitrite accumulation in batch reactors. Biodegradation 12(5):359-366

Bolzonella D, Innocentl L, Pavan P (2001) Denitrification potential enhancement by addition of anaerobic fermentation products from the organic fraction of municipal solid waste. Water Sci Technol 44(1):187-194

Çeçen F, Aktaș Ö (2004) Aerobic co-treatment of landfill leachate with domestic wastewater. Environ Eng Sci 21(3):303-312

Diamadopoulos E, Samaras P, Dabou X, Sakellaropoulos GP (1997) Combined treatment of leachate and domestic sewage in a sequencing batch reactor. Water Sci Technol 36(2-3):61-68

Gao D, Yin H, Liu L, Li X, Liang H (2013) Effects of idle time on biological phosphorus removal by sequencing batch reactors. J Environ Sci (China) 25(12):2396-2402

Gotvajn AŽ, Kalčíková G, Zupančič M, Zagorc-Končan J (2012) Determination of impact of landfill leachate to nitrification. Fresenius Environ Bull 21(8C):2447-2452

Guo H, Zhou J, Zhang S, Guo Z (2011) Characteristics of nitrogen and phosphorus removal in a sequencing batch reactor. J Environ Sci 23:s110-s113

Im J, Woo H, Choi M, Han K, Kim C (2001) Simultaneous organic and nitrogen removal from municipal landfill leachate using an anaerobic-aerobic system. Water Res 35(10):2403-2410

Isaacs SH, Henze M (1995) Controlled carbon source addition to an alternating nitrification-denitrification wastewater treatment process including biological P-removal. Water Res 29(1):77-89 
Kim D, Lee D, Keller J (2006) Effect of temperature and free ammonia on nitrification and nitrite accumulation in landfill leachate and analysis of its nitrifying bacterial community by FISH. Bioresour Technol 97(3):459468

Kuba T, Wachtmeister A, Van Loosdrecht MCM, Heijnen JJ (1994) Effect of nitrate on phosphorus release in biological phosphorus removal systems. Water Sci Technol 30(6):263-269

Kulikowska D, Bernat K (2013) Nitritation-denitritation in landfill leachate with glycerine as a carbon source. Bioresour Technol 142:297-303

Kurniawan TA, Lo W, Chan G, Sillanpää MET (2010) Biological processes for treatment of landfill leachate. J Environ Monit 12(11):2032-2047

Neczaj E, Okoniewska E, Kacprzak M (2005) Treatment of landfill leachate by sequencing batch reactor. Desalination 185:357-362

Park S, Choi KS, Joe KS, Kim WH, Kim HS (2001) Variations of landill leachate properties in conjunction with the treatment process. Environ Technol 22(6):639-645

Peng YZ, Gao JF, Wang SY, Sui MH (2003) Use of pH as fuzzy control parameter for nitrification under different alkalinity in SBR process. Water Sci Technol 47(11):77-84

Raghab SM, El Meguid AMA, Hegazi HA (2013) Treatment of leachate from municipal solid waste landfill. HBRC J 9(2):187-192

Renou S, Givaudan JG, Poulain S, Dirassouyan F, Moulin P (2008) Landfill leachate treatment: review and opportunity. J Hazard Mater 150(3):468-493

Rhee SK, Lee JJ, Lee ST (1997) Nitrite accumulation in a sequencing batch reactor during the aerobic phase of biological nitrogen removal. Biotechnol Lett 19(2):195-198

Sun F, Wu S, Liu J, Li B, Chen Y, Wu W (2012) Denitrification capacity of a landfilled refuse in response to the variations of $\mathrm{COD} / \mathrm{NO}_{3}-\mathrm{N}$ in the injected leachate. Bioresour Technol 103(1):109-115

Vadivelu VM, Keller J, Yuan Z (2007) Free ammonia and free nitrous acid inhibition on the anabolic and catabolic processes of Nitrosomonas and Nitrobacter. Water Sci Technol 56(7):89-97

Wang D, Li X, Yang Q, Zeng G, Liao D, Zhang J (2008) Biological phosphorus removal in sequencing batch reactor with single-stage oxic process. Bioresour Technol 99(13):5466-5473

Xie B, Xiong S, Liang S, Hu C, Zhang X, Lu J (2012) Performance and bacterial compositions of aged refuse reactors treating mature landfill leachate. Bioresour Technol 103(1):71-77

Zhou Y, Oehmen A, Lim M, Vadivelu V, Ng WJ (2011) The role of nitrite and free nitrous acid (FNA) in wastewater treatment plants. Water Res 45(15):4672-4682 